\title{
Mapping Model Challenge Community Learning (CLC) in Shaping Learning Independence in Banten Province
}

\author{
Romli Ardie, Syafrizal, Heni Pujiastuti, Kuswantoro \\ Non-formal education Department \\ Untirta \\ Serang, Indonesia \\ ardietea@untirta.ac.id
}

\begin{abstract}
The ability of citizens to learn is the most fundamental in the development of curriculum and learning nonformal education. Developing community residents learn independence is essential from andragogy competence or social pedagogic educators of non-formal education. Educators assumed competency gap has implications for the management of learning in shaping the independence of the learners. To deal with the differences and challenges in the management of Community Learning Center (CLC). CLC mapping and challenges in the future. Scans taken include: the ability to develop programs, program implementation guidelines, and quality of implementation of program performance in achieving the independence of the learners. Results of mapping and challenges in CLC in Banten province shows the development of the program by $70 \%$ in accordance with the development of the region, reaching $68 \%$ of new planned arrangements of operations, while the quality of new arrangements reached $57 \%$ which led to the independence of the learners.
\end{abstract}

Keywords-mapping and challenges, develop programs, program implementation, achievement of quality, independence learners

\section{INTRODUCTION}

CLC in Indonesia is generally institutional based managed by the Institute of Government and non-Government. The difference has implications for the management of developmental differences between CLC each other. Developmental differences caused by some components, such as: the differences in ownership, human resources manager the ability of funds, number and types of services [1]. States that judging from the level of achievement of the minimum quality standard, there are internal problems faced by CLC including: lacking of ability to develop programs, organization and execution of the program in accordance with the supposedly rarely conducted, minimal level of quality achievement has not been reached [2]. However, non-formal education so much, and the development of non-formal education are more advanced and get a place in community, then the non-formal education to get the parallel position in developing the quality of education in Indonesia.

The essence of school education is one of the efforts to improve the knowledge, attitudes, skills and abilities that allow citizens to learn to live independently. Education programs outside of school community members are expected to be able to develop its potential through skills development in order to improve the quality of life [3]. In developing the skills of a heterogeneous society with various potential, capacity for tutors who have certain competencies.

In building quality CLC tutors become central role in developing and studying a program. Based on observations indicate $65 \%$ CLC in Banten province is managed by a tutor with the level of education degree (bachelor). This is an opportunity for CLC to develop their potential in accordance with the potential in the area. However, there are still some CLC in Banten province, managed by tutors who have an undergraduate. It is assumed implications for the competences of the tutor, so it is assumed will meet obstacles in developing regions. Limitations of competences of tutor in managing or operating the CLC assumed to have implications for the development and independence.

Independence associated with the construction and become a very important factor in development. Independence is an attitude that promotes self-dependency in addressing various issues in order to achieve one goal, without closing ourselves to the possibilities of mutually beneficial cooperation. Aspects of independence is divided into three terms, namely: emotional self-reliance, economic independence and intellectual independence [4]. Associated with the development of nonformal education in the province of Banten third such independence need to be owned by a manager in managing the CLC. Tutors who have emotional independence and intellectual independence are assumed to develop the potential of the region in managing the CLC, while the management of CLC which have economic independence, assumed to be able to develop the potential of the tutor and the potential area for residents learning independence.

\section{METHOD}

In doing mapping and establishing the independence of learners, the researcher used a model based on the conditions of the area where the learners are. Model mapping was shown in Figure 1 below. 


\begin{tabular}{|c|c|c|c|c|c|c|}
\hline Suppliers & Inputs & $\begin{array}{c}\text { Input } \\
\text { Characteristics }\end{array}$ & Process & Outputs & $\begin{array}{c}\text { Output } \\
\text { Characteristics }\end{array}$ & Customers \\
\hline & & & $\begin{array}{l}\text { 2a. What is } \\
\text { the start of } \\
\text { the } \\
\text { process? }\end{array}$ & & & \\
\hline \multirow[t]{2}{*}{$\begin{array}{l}\text { 7. Who } \\
\text { are the } \\
\text { suppliers } \\
\text { of the } \\
\text { inputs? }\end{array}$} & $\begin{array}{l}\text { 6. What } \\
\text { are the } \\
\text { inputs of } \\
\text { the } \\
\text { process? }\end{array}$ & \multirow[t]{2}{*}{$\begin{array}{l}\text { 8. What } \\
\text { are the } \\
\text { character- } \\
\text { istics of } \\
\text { the } \\
\text { inputs? }\end{array}$} & $\begin{array}{l}\text { 1. What } \\
\text { is the } \\
\text { process? }\end{array}$ & $\begin{array}{l}\text { 3. What } \\
\text { are the } \\
\text { outputs } \\
\text { of the } \\
\text { process? }\end{array}$ & \multirow[t]{2}{*}{$\begin{array}{l}\text { 5. What } \\
\text { are the } \\
\text { character- } \\
\text { istics of } \\
\text { the } \\
\text { outputs? }\end{array}$} & \multirow[t]{2}{*}{$\begin{array}{l}\text { 4. Who } \\
\text { are the } \\
\text { customers } \\
\text { of the } \\
\text { outputs? }\end{array}$} \\
\hline & & & $\begin{array}{l}2 \mathrm{~b} \text {. What is } \\
\text { the end of } \\
\text { the } \\
\text { process? }\end{array}$ & & & \\
\hline
\end{tabular}

Fig. 1. Mapping the establishment of the independence of the learners

In mapping the CLC challenges in the future, in general there are three things that need to be considered, namely: input, process and output. Based on Figure 1 that map the input, need to know the needs of the learners, learners mencarai process, and the characteristics of the learners. Meanwhile, in mapping out the process, you need to know how to initiate, execute and terminate the learning process in the CLC. Furthermore, in mapping the output you need to know the process of completion, characteristics, and uses or benefits of learning for residents to learn after graduating from the CLC.

In this study, researcher used a qualitative approach, according to Bogdan and Taylor in qualitative research is a research procedure that produces descriptive data in the form of data written or spoken and observed behavior [5]. The research was conducted to describe the implementation of education programs implemented in the CLC. Independence and challenges in mapping PKBM in Banten province involving some CLC that spread across the districts or cities. Participatory research is a research completed through the democratic interaction between the instructor to participant [6]. CLC examined in this study were 45 CLC given its characteristics vary, so sampling was used with stratified random sampling technique.

\section{DISCUSSION}

The research was conducted through mapping CLC challenges in the future, the mapping includes activities and independent learners. Activities learners include: frequency of attendance the learners, the activities of people learn after attending learning, learning citizen participation in the learning process, the reconstruction result of learning to the development of the area. Meanwhile, mapping independence of learners, including the analysis after residents learned completion of the study (after study). The activities were established in the form of the establishment of an independent business group [7]. The main thing in the mapping of independence and challenge CLC is exploiting local potential.

CLC mapping results in realizing the independence of the learners is shown in Figure 2. In this figure, it appears that there are two responses that need to be done by the manager or tutor, namely explorer report and report suite. Results of mapping data collected indicate that the report is very dominant explorer lead to the leadership to strategy, while for the report suite is dominated by technology and finance.

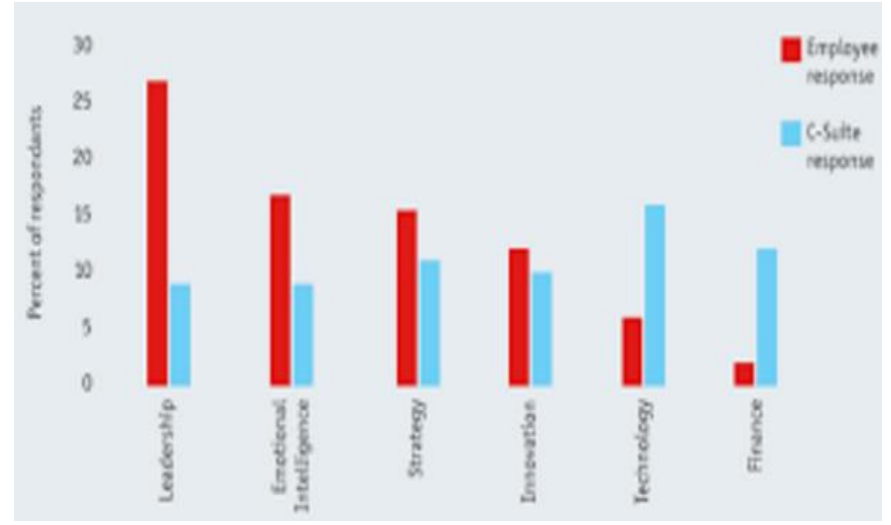

Fig. 2. Results of mapping and challenges to the independence of the learners

From 45 participants of CLC the sample in this study, obtained CLC mapping model and challenges in establishing the independence of the learners. Based on these images, as much as $70 \%$ CLC in Banten Province has shown the development of the program in accordance with the development of the region, the implementation of new $68 \%$ of its operations for the direnacanakan, while the quality of new arrangements reached $57 \%$ which led to the independence of the learners. In the framework of the independence of the learners, the necessary strategy that needs an advanced program CLC attention, including:

a. Categorization of the target group and location and scale of priorities, using the criteria of degree of poverty and opportunities for education services.

b. Preparation of the district or city as a base management planning, execution, control and evaluation of programs.

c. Program planning districts or cities in a comprehensive and integrated approach, oriented to community development according to the characteristics of the target group, the potential of communities and regions.

d. Planning support and facilitation programs at provincial and central levels, according to the needs of the district/city program locations.

Mapping independence CLC learners in Banten province actually allows communities can empower themselves. Guided by these principles, the community empowerment process will more easily be raised. These principles, professional performance required for program managers at the central, provincial and district or city at every stage of the program. Stages following program activities, from the planning, implementation and monitoring, the final assessment program and the impact of the program, carried out according to the rules and procedures for the management and output measured on each activity and the results of each phase [8].

\section{CONCLUSION}

Efforts are being made manager of CLC is to motivate citizens to learn to create their own jobs or work elsewhere. Utilization of local potential has not been a priority and efforts to establish the independence of the learners. CLC mapping results in realizing the independence of the learners, showed 
two responses are: explorer report and report suite. From the 45 CLC examined in this study, obtained 70\% CLC in Banten province already conducted the program in accordance with the development of the region, a new holding $68 \%$ of its planned operations, while the quality of new arrangements reached $57 \%$ which led to the independence of the learners.

\section{REFERENCES}

[1] [1] Curristine, T., Lonti, Z., \& Joumard, I. (2007). Improving Public Sector Efficiency: Challenges and Opportunities. OECD Journal on Budgeting, Volume 7 - No. 1.1-41.

[2] [2] Nur Djazifah, ER. 2005. Studi Layanan pada Anak Usia Dini di TPA Dharma Yoga Santi UNY dan Yogya. Yogyakarta: Kerjasama Studi PAUD dan Wanita

[3] [3] Kamil, Mustofa. 2009. Pendidikan Non Formal. Bandung: Alfabeta

[4] [4] Mu'tadin, Z. 2002. Pengantar Pendidikan dan Ilmu Perilaku Kesehatan. Yogyakarta: Andi Offset

[5] [5] Moleong, Lexy J. 2007. Metodologi Penelitian Kualitatif. Bandung: PT Remaja Rosdakarya Offset

[6] [6] Fakih, M. (1990). Parcipatory Research on Popular Economic Development. Amherst: University of Massachusetts.

[7] [7] Davidsson, P., \& Honig, B. (2003). The Role of Social and Human Capital. Journal of Business Venturing, 18(3). 301-331.

[8] [8] Berg, H. P. (2010). Risk Manajement: Procedures, Methods and Experiences. RT\&A \# 2(17), Vol.1. 79-95. 